\title{
Glial Fibrillary Acidic Protein-Apolipoprotein E (apoE) Transgenic Mice: Astrocyte-Specific Expression and Differing Biological Effects of Astrocyte-Secreted apoE3 and apoE4 Lipoproteins
}

\author{
Yuling Sun, ${ }^{1}$ Shan Wu, ${ }^{1}$ Guojun Bu, ${ }^{3}$ Moyosore K. Onifade, ${ }^{1}$ Shilen N. Patel, ${ }^{1}$ Mary Jo LaDu, ${ }^{4}$ \\ Anne M. Fagan, ${ }^{1}$ and David M. Holtzman ${ }^{1,2}$ \\ ${ }^{1}$ Department of Neurology and Center for the Study of Nervous System Injury, and Departments of 2Molecular Biology \\ and Pharmacology and ${ }^{3}$ Pediatrics and Cell Biology and Physiology, Washington University School of Medicine, St. Louis, \\ Missouri 63110, and 4Department of Pathology, University of Chicago, Chicago, Illinois 60637
}

The $\epsilon 4$ allele of apolipoprotein $E$ (apoE) is associated with increased risk for Alzheimer's disease (AD) and poor outcome after brain injury. In the CNS, apoE is expressed by glia, predominantly astrocytes. To define the potential biological functions of different human apoE isoforms produced within the brain, transgenic mice were generated in which human apoE3 and apoE4 expression is under control of the astrocyte-specific glial fibrillary acidic protein (GFAP) promoter. These animals were then bred back to apoE knock-out mice. Human apoE protein is found within astrocytes and the neuropil throughout development and into the adult period, as assessed by immunocytochemistry and immunoblot analysis in several GFAPapoE3 and E4 lines. Cultured astrocytes from these mice secrete apoE3 and apoE4 in lipoproteins that are high-density lipoprotein-like in size. When primary hippocampal neurons are grown in the presence of astrocyte monolayers derived from these transgenic mice, there is significantly greater neurite outgrowth from neurons grown in the presence of apoE3secreting astrocytes compared with apoE4-secreting or apoE knock-out astrocytes. These effects are not dependent on direct astrocyte-neuron contact and appear to require the lowdensity lipoprotein receptor-related protein. These data suggest that astrocyte-secreted, apoE3-containing lipoproteins have different biological effects than apoE4-containing lipoproteins. In addition to providing information regarding the role of astrocyte-secreted apoE lipoproteins in the normal brain, these animals will also be useful in models of both AD and CNS injury.

Key words: apolipoprotein E; transgenic; astrocyte; Alzheimer's disease; low-density lipoprotein receptor-related protein; receptor-associated protein
Apolipoprotein E (apoE) is a 299 amino acid lipid transport protein that participates in the regulation of plasma cholesterol and lipid metabolism. In humans, apoE has three major protein isoforms: E2 (Cys $\left.{ }^{112}-\mathrm{Cys}^{158}\right)$, E3 (Cys $\left.{ }^{112}-\mathrm{Arg}^{158}\right)$, and E4 $\left(\mathrm{Arg}^{112}-\mathrm{Arg}^{158}\right)$, products of alleles at a single gene locus (Mahley, 1988). Numerous epidemiological studies have shown that the $\epsilon 4$ allele of apoE is a major risk factor for Alzheimer's disease (AD) (for review, see Strittmatter and Roses, 1996). In addition, recent data suggest that apoE4 appears to be a risk factor for poor outcome after head trauma (Nicoll et al., 1995; Teasdale et al., 1997), cerebral hemorrhage (Alberts et al., 1995), cardiac bypass (Tardiff et al., 1997), and possibly stroke (Slooter et al., 1997), as well as to influence the age of onset of Parkinson's disease (Zarepesi et al., 1997). These data suggest that apoE may play a direct role in the pathophysiology of both AD and response to CNS injury.

In addition to the liver, apoE is expressed at high levels in the brain (Mahley, 1988). Within the CSF, apoE is found in highdensity lipoprotein (HDL)-like lipoprotein particles (Pitas et al.,

Received Dec. 16, 1997; revised Feb. 3, 1998; accepted Feb. 9, 1998.

This work was supported by National Institutes of Health Grants AG13956 (D.M.H.) and AG05681 (G.B. and D.M.H.), Alzheimer's Association Grant RG396-26 (D.M.H.), and a Paul Beeson Physician Faculty Scholar Award from American Federation for Aging Research (D.M.H.). We thank Maia Parasadanian for her help with tissue preparation.

Correspondence should be addressed to David M. Holtzman, Washington University School of Medicine, Department of Neurology, Center for the Study of Nervous System Injury, 660 South Euclid Avenue, Box 8111, St. Louis, MO 63110. Copyright (C) 1998 Society for Neuroscience $0270-6474 / 98 / 183261-12 \$ 05.00 / 0$ 1987b). A study in humans demonstrated that apoE in CSF is produced within the blood-brain barrier and is not derived from plasma (Linton et al., 1991). Thus, apoE derived from cells within the CNS is likely to mediate the neurobiological effects of apoE in different settings. ApoE within the CNS is produced primarily by astrocytes (Boyles et al., 1985; Pitas et al., 1987a), with microglia also capable of apoE synthesis (Nakai et al., 1996; Stone et al., 1997). ApoE receptors are also present on neural cells. Astrocytes express the low-density lipoprotein receptor (LDLR) (Pitas et al., 1987a; Poirier et al., 1993), and neurons primarily express the LDLR-related protein (LRP) (Moestrup et al., 1992; Wolf et al., 1992; Rebeck et al., 1993; Bu et al., 1994), although expression of other LDLR family members by neurons has been reported (Christie et al., 1996; Kim et al., 1996). In vitro, astrocytes secrete apoE (Pitas et al., 1987a), and our recent studies demonstrate that nascent astrocyte-secreted apoE is associated with discoidal HDL-like particles, distinct from spherical apoEcontaining CSF lipoprotein particles (LaDu et al., 1998). In vivo, expression of apoE by astrocytes is upregulated after injury (Poirier et al., 1991). Several in vitro studies have demonstrated that certain forms of apoE and lipoproteins can affect functions such as neurite outgrowth (Handelmann et al., 1992; Nathan et al., 1994; Holtzman et al., 1995b). In vivo studies with apoE knock-out mice also suggest that apoE may play a role in structural plasticity during aging (Masliah et al., 1995) and cell death after injury (Chen et al., 1997; Laskowitz et al., 1997).

To study the in vitro and in vivo role of human apoE isoforms expressed specifically by astrocytes, we have generated transgenic 
mice in which expression of human apoE3 and apoE4 is under the control of the glial fibrillary acid protein (GFAP) promoter. These animals were then bred back to apoE knock-out (-/-) mice so that only human apoE protein is expressed in the animals. We demonstrate that (1) apoE3 and apoE4 are expressed in the brain by astrocytes during development and in adult mice; (2) apoE3 and apoE4 are secreted by cultured astrocytes in lipoprotein particles that are HDL-like in size; (3) hippocampal neurite outgrowth is greater in the presence of astrocytes that secrete apoE3 versus those that secrete apoE4 or no apoE; and (4) the effect of astrocyte-secreted apoE3 appears to require LRP and is not dependent on neuron-glia contact. Our results suggest that astrocyte-secreted human apoE isoforms have different neurobiological activities and that GFAP-apoE transgenic mice may be useful to dissect the functions of apoE isoforms produced by astrocytes in normal and disease states.

\section{MATERIALS AND METHODS}

Construct preparation and generation of transgenic mice. The lac $Z$ fragment was removed from the hgfa2-lac $Z$ transgene (Brenner et al., 1994) after BamHI digestion. A 1050 bp fragment of apoE3 and apoE4 was amplified by the PCR from the cytomegalovirus-apoE3 plasmid (pCMVapoE3) and pCMV-apoE4 plasmids (LaDu et al., 1994) to add a BamHI site at the $5^{\prime}$ and $3^{\prime}$ ends of the apoE cDNA with the following primers: $5^{\prime}$-ccggggatccegccaatcacagg- $3^{\prime}$ and $5^{\prime}$-ccggggatcctctagaggatccc- $3^{\prime}$. The reaction was performed at $94^{\circ} \mathrm{C}$ for $5 \mathrm{~min}$, followed by 25 cycles at $94^{\circ} \mathrm{C}$ for $1 \mathrm{~min}, 65^{\circ} \mathrm{C}$ for $1 \mathrm{~min}$, and $72^{\circ} \mathrm{C}$ for $30 \mathrm{sec}$, and then the reaction was completed at $72^{\circ} \mathrm{C}$ for $10 \mathrm{~min}$. The PCR reaction mixture was the same as listed in the following section, except that amplification was performed in 10\% dimethylsulfoxide (DMSO). The PCR products were purified and digested with BamHI. The apoE3 and apoE4 cDNAs were ligated into the BamHI site between the hgfa2 and mP1-poly(A) fragments (see Fig. $1 A$ ) to form plasmids pgfa2-apoE3 and pgfa2-apoE4. The entire apoE region of these plasmids was sequenced before preparing the DNA for oocyte injection. These plasmids were then digested with Eco RI, and the $3.2 \mathrm{~kb}$ transgene fragment (Fig. $1 A$ ) was eluted from an agarose gel, purified, and used for pronuclear injection (strain B6/CBA) as described (Hogan et al., 1986). Integration of the transgene was determined by PCR and Southern blot analysis on genomic DNA isolated from mouse tails (see below). Once GFAP-apoE3 and GFAP-apoE4 transgenic mice were produced, they were bred to apoE knock-out $(-/-)$ mice $(>10$ backcrosses onto C57Bl6 background; The Jackson Laboratory, Bar Harbor, ME).

Southern blot and PCR analysis. Twenty micrograms of genomic DNA extracted from a mouse tail was digested with EcoRI, separated in $1.0 \%$ agarose gel and transferred to a positively charged nylon membrane (GeneScreen; DuPont NEN, Boston, MA) by capillary blotting as described (Sambrook et al., 1989). Blots were placed in a vacuum oven at $80^{\circ} \mathrm{C}$ for $2 \mathrm{hr}$, hybridized with a random-primed ${ }^{32} \mathrm{P}$-labeled mouse apoE cDNA probe as described (Holtzman et al., 1992), air-dried, and exposed to $\mathrm{x}$-ray film (Hyperfilm MP, Amersham) at $-70^{\circ} \mathrm{C}$ with intensifying screens. In addition, films were exposed to a phosphorimaging screen, and transgene copy number was determined by comparison of the signal obtained for the endogenous mouse $(\sim 3 \mathrm{~kb})$ and transgenic human apoE $(\sim 1 \mathrm{~kb})$ bands. In separate experiments, we found that the mouse apoE cDNA probe recognized full-length human and mouse apoE cDNAs to the same extent on slot blots performed as described (Mobley et al., 1988). To determine the presence of the GFAP-apoE transgene by PCR, we analyzed mouse tail DNA with the following primers: $5^{\prime}-$ ccagggggtgttgccaggggcacc- $3^{\prime}$ and $5^{\prime}$-tccagttccgatttgtaggccttcaactcc- $3^{\prime}$. The PCR reaction was in $50 \mu \mathrm{l}$ and contained $2 \mu \mathrm{l}$ of DNA ( $\sim 50 \mathrm{ng}), 2.5$ $\mu \mathrm{l}$ of each primer $(10 \mu \mathrm{M}$ stock solution), $10 \times$ PCR buffer $(20 \mathrm{~mm}$ Tris-HCl, pH 8.0, 0.1 mm EDTA, 1 mm DTT, and 50\% glycerol), $200 \mu \mathrm{M}$ $\mathrm{dNTP}$, and $0.25 \mu \mathrm{l}$ of Taq polymerase ( $5 \mathrm{U} / \mu \mathrm{l}$; Life Technologies, Grand Island, NY). The reaction was performed at $94^{\circ} \mathrm{C}$ for $3 \mathrm{~min}$, followed by 35 cycles at $94^{\circ} \mathrm{C}$ for $45 \mathrm{sec}, 65^{\circ} \mathrm{C}$ for $40 \mathrm{sec}$, and $72^{\circ} \mathrm{C}$ for $1 \mathrm{~min}$, and then the reaction was completed at $72^{\circ} \mathrm{C}$ for $10 \mathrm{~min}$. This reaction generates a PCR product of $\sim 500 \mathrm{bp}$. To analyze for the presence of the intact or neo-disrupted version of the mouse apoE gene (Piedrahita et al., 1992), we used the following primers: 5'-tgtcttccactattggctcg-3' and 5'ctctgtgggccgtgctgttg- $3^{\prime}$. The PCR mixture was the same as listed above except for the addition of $10 \%$ DMSO. The reaction was performed at $94^{\circ} \mathrm{C}$ for $3 \mathrm{~min}$, followed by 35 cycles at $94^{\circ} \mathrm{C}$ for $45 \mathrm{sec}, 60^{\circ} \mathrm{C}$ for $40 \mathrm{sec}$, and $72^{\circ} \mathrm{C}$ for $1 \mathrm{~min} 30 \mathrm{sec}$, and then the reaction was completed at $72^{\circ} \mathrm{C}$ for $10 \mathrm{~min}$. This reaction generates a PCR product of $\sim 2.5 \mathrm{~kb}$ for the neo-disrupted mouse apoE gene and a fragment of $\sim 1.75 \mathrm{~kb}$ for the wild-type mouse apoE gene.

Tissue preparation and animal surgery. For histological analyses, animals were perfused transcardially with $0.1 \mathrm{M}$ PBS, $\mathrm{pH}$ 7.4. The brain was removed, and one hemibrain was frozen in powdered dry ice and stored at $-70^{\circ} \mathrm{C}$ until used for Western blot analysis. The other hemibrain was immersion-fixed in $4 \%$ paraformaldehyde in PBS for $24 \mathrm{hr}$ at $4^{\circ} \mathrm{C}$. After fixation, the brain was cryoprotected in $30 \%$ sucrose in PBS at $4^{\circ} \mathrm{C}$ and frozen in powdered dry ice. Tissue sections were then cut in the coronal plane at $40 \mu \mathrm{m}$ on a freezing sliding microtome. For entorhinal cortex lesions, mice were anesthetized and then given unilateral (right-sided) aspirative lesions of the perforant path as described previously (Fagan et al., 1996b). Lesion placement was verified by examination of cresyl violet-stained sections through the lesion site.

Immunohistochemistry, immunofluorescence, and Western blotting. Forty-micrometer free-floating sections through the forebrain and hindbrain were processed for peroxidase immunohistochemistry or immunofluorescence using the following primary antibodies: goat anti-apoE (1:30,000; Calbiochem, La Jolla, CA), rabbit anti-apoE (1:8000) raised against recombinant human apoE (Fagan et al., 1996a), and a rat antiGFAP (1:500) monoclonal antibody (Zymed, San Francisco, CA). Tissue sections were incubated in biotinylated secondary antibodies, and detection of the peroxidase reaction product with diaminobenzidine (DAB) was performed with the ABC Elite kit (Vector Laboratories, Burlingame, CA) as described previously (Holtzman et al., 1995a). For doublelabeling immunofluorescence studies, goat anti-apoE and rat anti-GFAP were applied sequentially to sections, followed by coapplication of fluorescein-labeled anti-rat and indocarbocyanine-labeled anti-goat secondary antibodies as described (Fagan et al., 1996b). Sections were mounted on slides with Vectashield mounting media (Vector) and viewed via fluorescence microscopy. For Western blots, forebrain samples were lysed in $20 \mathrm{~mm}$ Tris, $\mathrm{pH} 8.0,150 \mathrm{~mm} \mathrm{NaCl}, 1 \%$ Nonidet P-40, $10 \%$ glycerol, $1 \mu \mathrm{g} / \mathrm{ml}$ leupeptin, and $10 \mu \mathrm{g} / \mathrm{ml}$ aprotinin and then centrifuged at $15,000 \mathrm{rpm}$ in a microfuge. Protein assays were then performed on the supernatant of each sample. For SDS-PAGE, samples containing $2 \times$ reducing Laemmli buffer (4\% SDS) were boiled for $5 \mathrm{~min}$ and electrophoresed on $10 \%$ gels with equal amounts of total protein loaded per lane. Proteins were then transferred to nitrocellulose, and immunoblotting was performed with goat (1:5000) or rabbit anti-apoE (1:5000) antibodies described above. Bands were visualized with enhanced chemiluminescence (ECL, Amersham).

Gel filtration chromatography of astrocyte-conditioned media. Serumfree, astrocyte-conditioned media (see below) was concentrated (Centriplus-10; Amicon, Beverly, MA) 50-fold before fractionation. One milliliter of concentrated astrocyte-conditioned media was fractionated by gel filtration chromatography using FPLC with tandem Superose 6 columns (Pharmacia, Piscataway, NJ) in $0.02 \mathrm{M}$ sodium phosphate, $0.05 \mathrm{M}$ $\mathrm{NaCl}, \mathrm{pH} 7.4,0.03 \%$ EDTA, and $0.02 \%$ sodium azide. Sixty fractions of $400 \mu \mathrm{l}$ each were collected and analyzed. Flow rate of the column was 4 $\mathrm{ml} / \mathrm{min}$ at $20^{\circ} \mathrm{C}$. For SDS-PAGE, samples containing $2 \times$ nonreducing Laemmli buffer (4\% SDS) were boiled for $5 \mathrm{~min}$ and electrophoresed on $10-20 \%$ SDS-Tricine gels. Gels were transferred to Immobilon-P membranes and probed for apoE immunoreactivity as described (LaDu et al., 1998) (see above) and visualized by ECL (Amersham).

Primary astrocyte and hippocampal cultures. Forebrain astrocytes were prepared from individual postnatal day 1-2 (P1-P2) mouse pups and cultured in either T-75 flasks or in 24-well plates as described (Rose et al., 1993; Narita et al., 1997). PCR was performed on pup tail DNA to determine the presence or absence of the GFAP-apoE transgene. Once astrocytes were confluent, they were washed with serum-free media, and then E19 hippocampal neurons from C57Bl6 mice (density, 100 cells/ $\mathrm{mm}^{2}$ ) were plated either (1) directly on top of the astrocytes in N2 media as described (Narita et al., 1997), or (2) onto poly-D-lysine-coated coverslips in N2 media with four paraffin balls on the surface around the edge of each coverslip. For the latter experiments, once the neurons attached (within $4 \mathrm{hr}$ ), the coverslips were removed and flipped over into 24-well plates containing an astrocyte monolayer and N2 media such that the neurons were $\sim 2-3 \mathrm{~mm}$ above the surface of the astrocytes but not in direct contact, as described (Goslin and Banker, 1991). Purified recombinant $39 \mathrm{kDa}$ receptor-associated protein (RAP), anti-LRP IgG, and nonimmune rabbit IgG, prepared as described (Bu et al., 1993), were 
A.

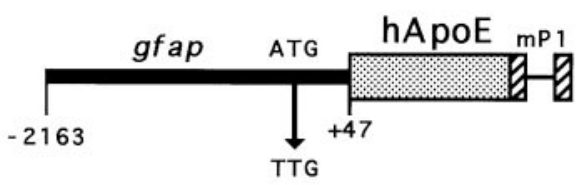

B.

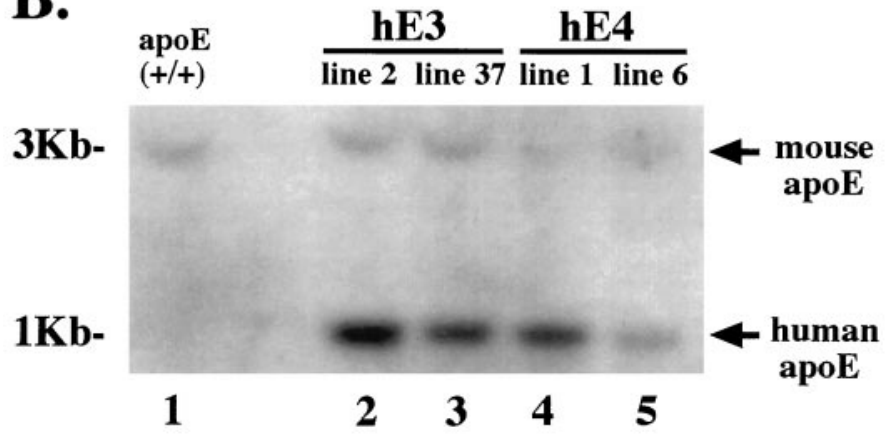

Figure 1. GFAP-apoE construct used to generate transgenic mice expressing human apoE3 and apoE4 in the brain and Southern blot analysis for apoE in founder mice. $A$, Human apoE3 and apoE4 cDNAs $(h A p o E)$ were subcloned behind a human glial fibrillary acidic protein ( $g$ fap $)$ promoter described by Brenner et al. (1994). B, Southern blot analysis using a ${ }^{32} \mathrm{P}$-labeled cDNA probe to mouse apoE reveals the presence of human $(\sim 1 \mathrm{~kb})$ and mouse apoE $(\sim 3 \mathrm{~kb})$ DNA in different apoE3 $(h E 3)$ and apoE4 $(h E 4)$ transgenic lines. Copy number is variable from line to line.

added to media at the time of neuronal plating in some experiments. Cells were cultured for $44 \mathrm{hr}$ at $37^{\circ} \mathrm{C}$ in a humidified $5 \% \mathrm{CO}_{2}$ incubator, fixed with $4 \%$ paraformaldehyde in PBS, and stained with antibodies to MAP-2 as described (Narita et al., 1997) to identify neuronal cells. MAP-2-IR neurites and cells were assessed using images from a video camera projected onto a computer screen and then analyzed with the NIH Image analysis program (version 1.57). For neurons grown on astrocyte monolayers, neurites were identified based on visualization of MAP-2-IR neurites. Neurites were traced from the cell body along the neurite until the MAP-2-IR was no longer visualized. For neurons grown on coverslips, neurites were identified with both MAP-2-IR as well as with phase-contrast microscopy. The entire extent of all neurites could unambiguously be identified in this manner. Beginning at the center of each tissue culture well or the center of each coverslip, all isolated neurons were evaluated until 20 were encountered per well. To determine the number of neurites per neuron, the total number of neurites longer than one cell diameter was counted. To determine mean neurite length, the lengths of all neurites greater than one cell body were measured and the lengths of the neurites were divided by the number of neurites measured. To determine mean neurite length per cell, the lengths of all neurites greater than one cell body were measured and divided by the number of cells assessed. All assays were performed in triplicate or quadruplicate, and each experiment was repeated two or three times with each transgenic line. The investigator assessing neurite length was blind to astrocyte genotype. Data are presented as mean \pm SEM and were analyzed with ANOVA followed by Bonferroni $t$ test with significance set at $p<0.05$.

\section{RESULTS}

To express human apoE isoforms in astrocytes, we subcloned apoE3 and apoE4 cDNAs behind the $g f a 2$ segment of the human GFAP promoter construct (Fig. $1 A$ ). This construct has been shown previously to direct in vivo expression of a lac $Z$ reporter gene to astrocytes in a developmental pattern similar to that seen for both endogenous GFAP and apoE (Brenner et al., 1994; Mouchel et al., 1995). GFAP-apoE transgenic mice were generated by microinjection of DNA into fertilized mouse eggs. Four GFAP-apoE3 and 9 GFAP-apoE4 founder mice were produced

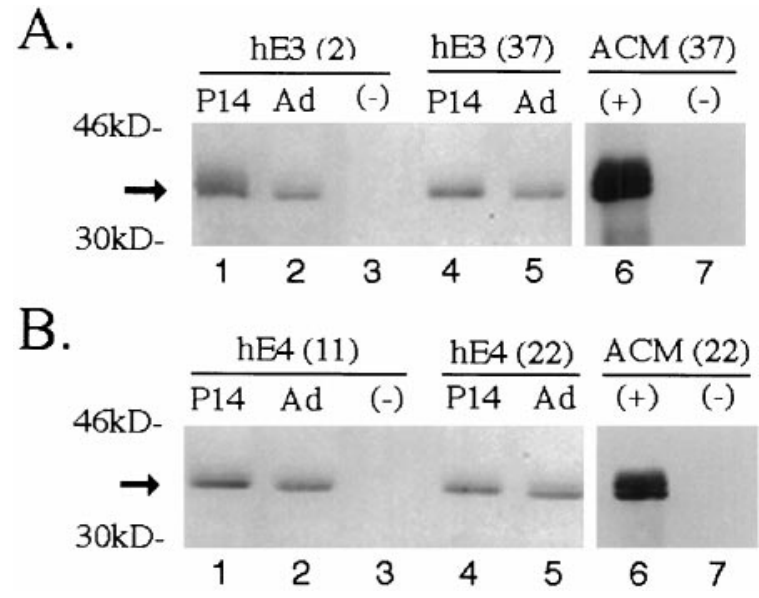

Figure 2. Western blot analysis of human apoE in forebrain lysates and concentrated astrocyte-conditioned media $(A C M)$ from transgenic mice expressing apoE3 $(h E 3 ; A)$ or apoE4 $(h E 4 ; B)$. In forebrain samples, $50 \mu \mathrm{g}$ of detergent-soluble protein was loaded per lane. Human apoE protein is detected with goat anti-human apoE antibody in the P14 and adult $(A d)$ brains of $h E 3$ (lines 2 and 37) and $h E 4$ (lines 11 and 22) transgenic mice but not in nontransgenic (-) apoE knock-out littermates. Astrocytes derived from transgenic $(+)$ animals $(h E 3$, line $37 ; h E 4$, line 22$)$ and from nontransgenic $(-)$ apoE knock-out littermates were cultured until confluent and washed, and serum-free media were collected for $48 \mathrm{hr}$. Media were concentrated 50 -fold, and $3 \mu \mathrm{l}$ was loaded per lane. Human apoE is detected in the serum-free ACM from GFAP-apoE3 line 37 and GFAPapoE4 line 22 but not in the media of astrocytes derived from nontransgenic apoE knock-out littermates. Arrow indicates position of apoE.

and identified as transgenic using the PCR as well as by Southern blotting of tail DNA. An example of a Southern blot demonstrating the presence of both the endogenous mouse apoE gene as well as GFAP-apoE transgene DNA in several founder animals is shown in Figure $1 B$. Transgene copy number was variable between transgenic lines and ranged from 3 to 13 .

To obtain mice that expressed human apoE in the absence of mouse apoE, all founder mice were bred to apoE knock-out $(-/-)$ mice for two generations to produce F2 mice that were hemizygous for the GFAP-apoE3 or E4 transgene and that were mouse apoE-/-. To determine which transgenic lines expressed human apoE protein, we analyzed these F2 offspring by performing immunohistochemistry and Western blotting with both rabbit and goat anti-apoE antibodies. Analysis revealed that two GFAPapoE3 (lines 2 and 37) and five GFAP-apoE4 (lines 1, 3, 11, 19, and 22) expressed human apoE. The expression of human apoE was developmentally regulated in a pattern similar to that seen for both endogenous GFAP and apoE (Poirier et al., 1991; Mouchel et al., 1995), with detectable levels at P1 (data not shown), higher levels at P14, and slightly lower levels in adults (Fig. 2). In quantitative Western blots, we found that expression of apoE in GFAP-apoE hemizygous animals varied between lines. Levels of apoE in forebrain samples of adult hemizygous animals ranged from 0.12 to $0.3 \mu \mathrm{g} / \mathrm{mg}$ of detergent-soluble protein, similar to levels of human apoE detected in samples of adult human cortex ( $\sim 0.4-0.5 \mu \mathrm{g} / \mathrm{mg}$ detergent-soluble protein; data not shown).

In immunohistochemical experiments, human apoE immunoreactivity (IR) in the GFAP-apoE transgenics appeared to label astrocytes and the neuropil throughout the brain, with an example of typical staining in hippocampus shown in Figure $3 A-D$. This pattern of staining is very similar to that seen for endogenous mouse apoE in wild-type animals (Fig. $3 E, F$ ). During development and in adult animals, human apoE-IR remained con- 

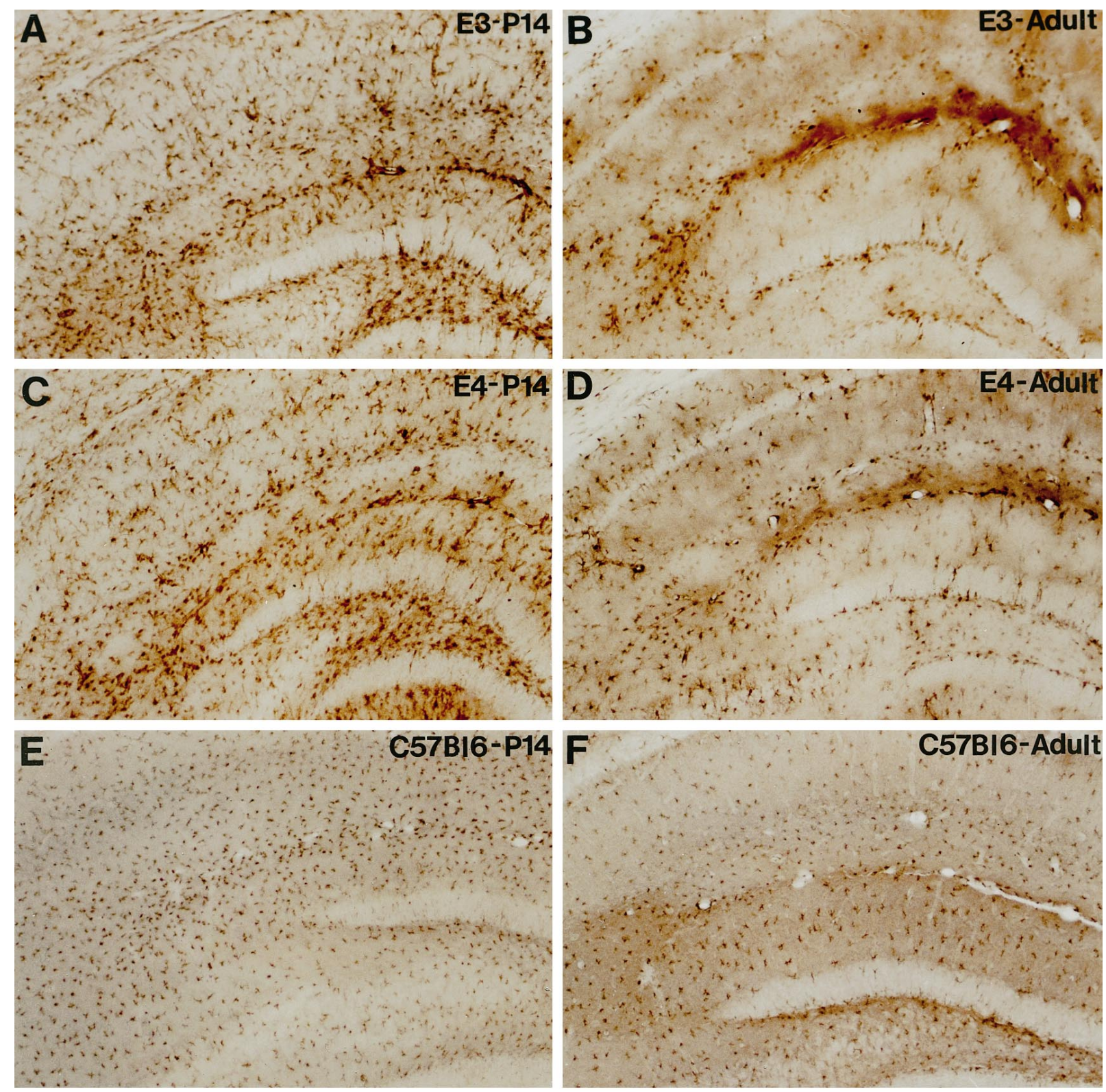

G

apoE(-/)

Figure 3. ApoE immunoreactivity is present in the brain of GFAP-apoE3 and GFAP-apoE4 mice. GFAP-apoE3 line 37 ( $A, B)$ and GFAP-apoE4 line $22(C, D)$ mice on a mouse apoE-/- background were immunostained with a goat anti-apoE antibody. There was strong staining of cells, which by morphology appear to be astrocytes in the hippocampus in both $\mathrm{P} 14(A, C)$ and adult $(B, D)$ mice. In addition to staining in glial cell bodies and their processes, apoE-IR also appears to be present in the neuropil. Qualitatively similar apoE-IR is seen in cells that appear to be glial in C57Bl6 apoE $+/+$ mice in both P14 $(E)$ and adult animals $(F)$. ApoE-IR is not observed in the hippocampus of an apoE-/- adult mouse $(G)$. Scale bar, $130 \mu \mathrm{m}$. 

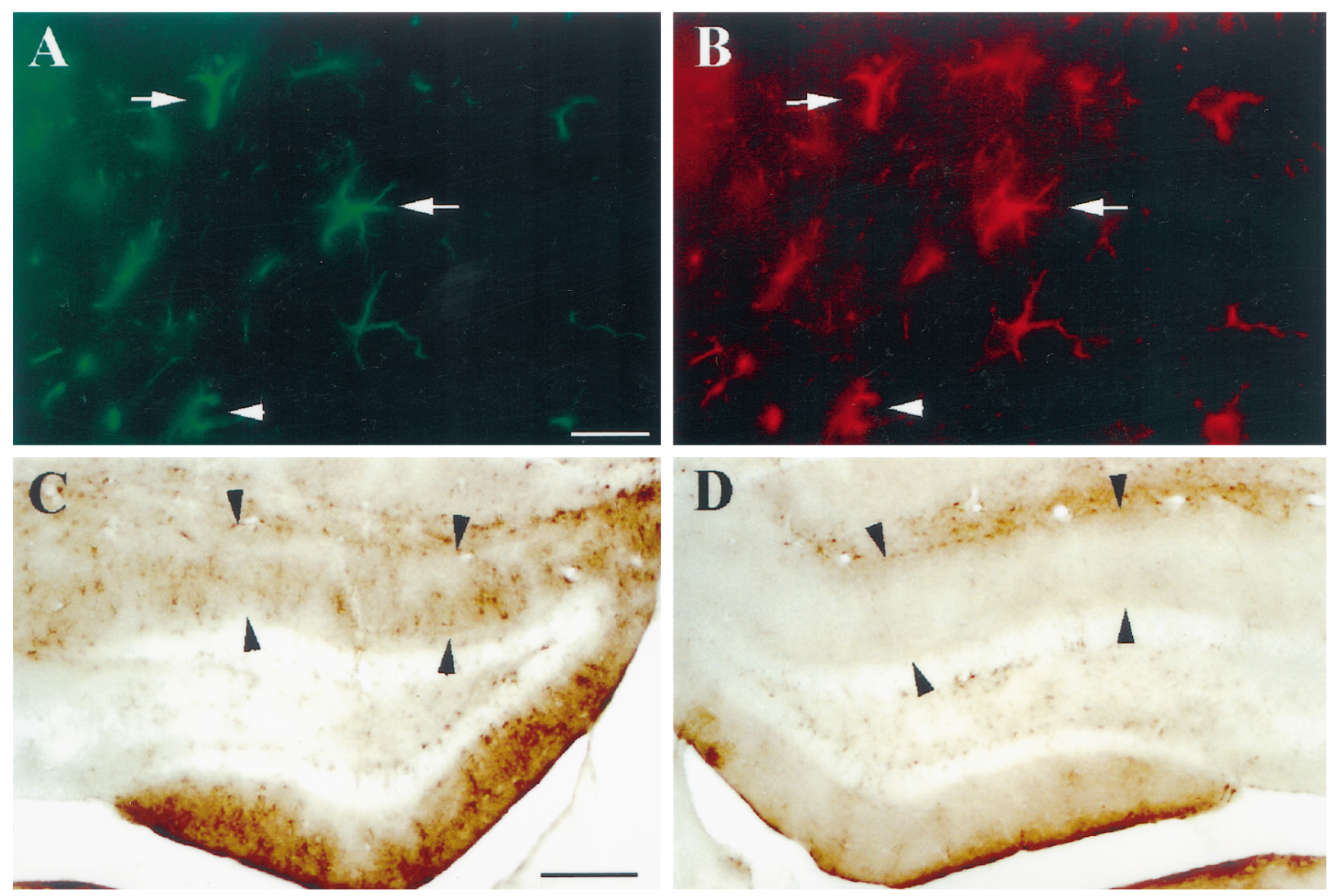

Figure 4. GFAP and human apoE are co-localized, and apoE immunoreactivity is increased in regions of denervation in GFAP-apoE transgenic mice. A section through the hippocampus of an adult GFAP-apoE3 line 37 mouse was stained with a rat anti-GFAP antibody $(A$, green $)$ and a goat anti-apoE antibody $(B, r e d)$. Cells that are GFAP-immunoreactive are also immunoreactive for apoE (arrows). Three days after unilateral (right) entorhinal cortex lesion in an adult GFAP-apoE4 line 19 mouse, apoE-IR is clearly increased within astrocytes and the neuropil of the denervated outer molecular layer of the dentate gyrus $(C)$. On the nonlesioned side $(D)$, apoE-IR is present but is not upregulated. In $C$ and $D$, the dorsal blade of the outer molecular layer is bracketed by arrowheads. Scale bars: $A, B, 2 \mu \mathrm{m} ; C, D, 100 \mu \mathrm{m}$.

fined to glia and the neuropil, with no clear staining of neuronal cell bodies. To confirm that apoE-IR was in astrocytes, we performed double-labeling experiments with GFAP and apoE antibodies on adult brain sections and used immunofluorescence microscopy to visualize stained cells. We observed an overlapping pattern of cellular staining for apoE and GFAP in all brain regions examined, including the hippocampus (Fig. 4A,B). To examine the regulation of human apoE expression by the GFAP promoter in response to brain injury, we performed lesions of the entorhinal cortex in several GFAP-apoE3 (lines 2 and 37) and GFAP-apoE4 (lines 11 and 19) adult animals. The results were similar with all animals, and an example from a GFAP-apoE4 line 19 animal that expresses apoE4 at high levels during development (P1-P21) but at lower levels in the adult period than other lines is illustrated here. Three days after entorhinal cortex lesion, there was a clear upregulation of apoE-IR in the denervated outer molecular layer of the dentate gyrus (Fig. 4C,D), the terminal zone of axotomized neurons in the entorhinal cortex. The increase in apoE-IR was seen in astrocytes as well as in the surrounding neuropil. Endogenous rat apoE and GFAP have been shown previously to be regulated in a similar pattern after entorhinal cortex lesion (Poirier et al., 1991; Fagan and Gage, 1994), demonstrating that in our model, apoE expression in the brain is recapitulated in a similar way to that seen normally and after injury.
In addition to detection of apoE-IR in astrocytes in vivo, we also produced forebrain glial cultures ( $>95 \%$ astrocytes) from GFAP-apoE transgenic mice and looked for evidence of apoE expression. All GFAP-apoE3 and apoE4 lines were found to secrete apoE, whereas apoE was not detectable in the media from cultures of nontransgenic apoE-/- littermates (Fig. 2). Levels of apoE present in the culture media after $3 \mathrm{~d}$ ranged from $\sim 0.5$ to $2 \mu \mathrm{g} / \mathrm{ml}$ in different lines. To determine whether apoE from astrocytes was secreted in lipoprotein particles, serum-free astrocyte-conditioned media was collected, concentrated 50-fold, and fractionated by gel filtration chromatography. The majority of the apoE was detected in fractions corresponding to particles the size of plasma HDL (Fig. 5).

Several previous studies have demonstrated that apoE3enriched lipoproteins enhance, whereas apoE4-enriched lipoproteins either decrease or have no effect on neurite outgrowth in PNS neurons and in neuronal cell lines (Nathan et al., 1994; Bellosta et al., 1995; Holtzman et al., 1995b; Fagan et al., 1996a). We sought to determine whether apoE3 and apoE4 secreted directly by cells that normally produce apoE in the brain (i.e., astrocytes) would affect neurite outgrowth from primary CNS neurons. First, we generated primary forebrain glial cultures from individual P1 pups from the different GFAP-apoE3 and GFAPapoE4 transgenic lines as well as from nontransgenic apoE-/littermates. Once astrocyte monolayers were confluent, two dif- 


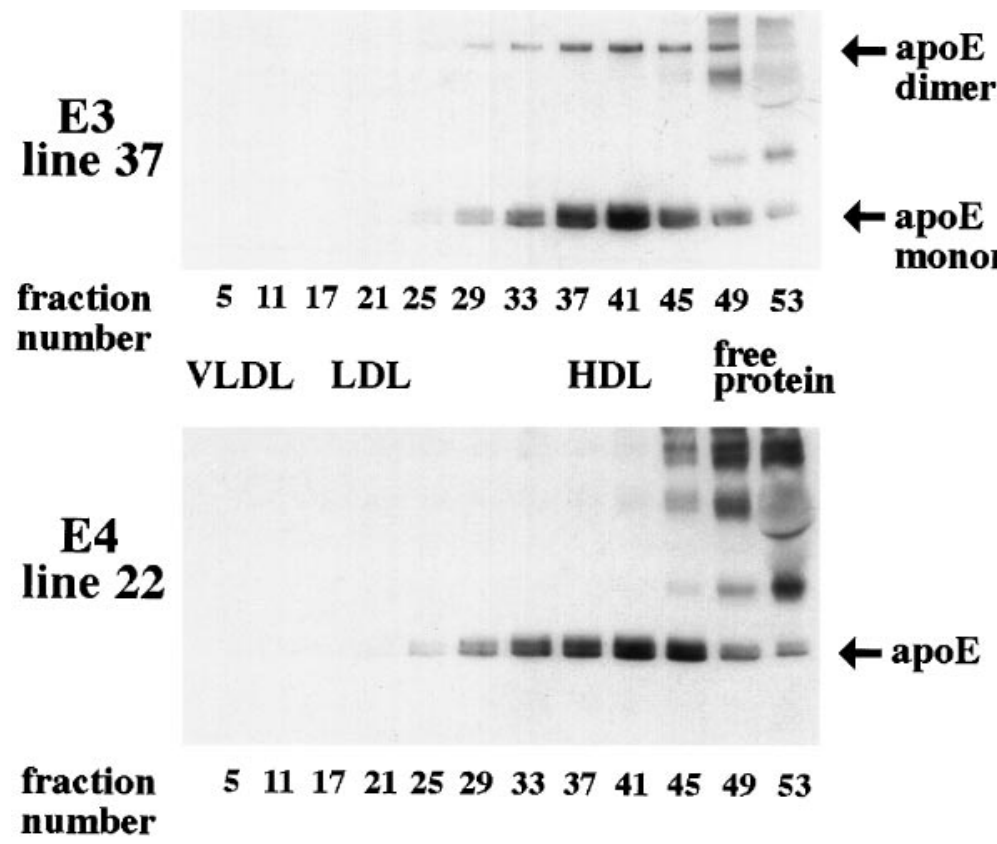

Figure 5. Western blot analysis of selected fractions from gel filtration chromatography of serum-free conditioned media from transgenic astrocytes expressing apoE3 (E3, line $37)$ or apoE4 (E4, line 22). Human apoE, as detected with rabbit anti-human apoE antisera, was present in fractions eluting in the size range of plasma HDL. The blot was developed with ECL. Arrows indicate positions of apoE $(\sim 36 \mathrm{kDa})$ monomer $(E 3, E 4)$, and $(\sim 72 \mathrm{kDa})$ dimer $(E 3)$

ferent kinds of experiments were performed. In the first set of experiments, glial cultures were washed with serum-free media, and embryonic day 19 (E19) primary hippocampal neurons (from C57Bl6 mice) were plated at low density directly on top of the astrocyte monolayers. In a second set of experiments, E19 primary hippocampal neurons were plated on poly-D-lysine-coated coverslips with small paraffin balls around the edge of the coverslip according to the method of Goslin and Banker (1991). Once the neurons attached (3-4 hr), the coverslips were flipped over and placed on top of either GFAP-apoE3, GFAP-apoE4, or apoE-/- astrocytes. Thus, in the second set of experiments, the neurons were exposed to the astrocyte-conditioned media but were not in direct contact with the glial monolayer. In both experiments described, cells were fixed $44 \mathrm{hr}$ after plating and stained with an antibody to MAP-2 to assist in identifying neurons and their processes, and neurite outgrowth was quantified using an image analysis system. We found that regardless of whether neurons were plated directly on top of the glial monolayer or were grown on coverslips in the presence of astrocyteconditioned media, neurite outgrowth was greater in the presence of GFAP-apoE3 compared with GFAP-apoE4 and apoE-/astrocytes (Figs. 6-8). Both mean MAP-2-IR neurite length as well as total MAP-2-IR neurite length per neuron were significantly greater in the presence of GFAP-apoE3 astrocytes (Fig. 8). In contrast, the number of MAP-2-IR neurites per neuron was not significantly different among the different transgenic lines (data not shown). The differential effects on neurite outgrowth were seen using two apoE3 and three apoE4 transgenic lines. Attenuated neurite outgrowth in the presence of GFAP-apoE4 astrocytes was not caused by lower levels of apoE secretion by these cells compared with GFAP-apoE3 astrocytes. ApoE4 levels in astrocyte-conditioned media were equal to or greater than levels of apoE3 in some experiments. It is of note that MAP-2 is a neuron-specific marker that strongly stains cell bodies and dendrites, although it may be excluded from some axons as they mature in culture (Goslin and Banker, 1991). In the neurons plated on astrocytes, MAP-2-IR was used to identify and assess neurite length. It is possible that the tip of every neurite was not visualized under these conditions. In experiments with neurons grown directly on coverslips, however, this was not the case rule. Under these conditions, we used both MAP-2-IR as well as phase-contrast microscopy to assist in tracing neurites. The full extent of all neurites could be unambiguously determined in this manner. Because stimulatory effects of astrocyte-secreted apoE3 were observed using this technique, apoE3 is clearly influencing total neurite outgrowth under these conditions.

In previous studies, it was shown that the stimulatory effects of apoE3-enriched, plasma-derived lipoproteins on neurite outgrowth appear to require interactions with the LRP (Bellosta et al., 1995; Holtzman et al., 1995b; Fagan et al., 1996a). To determine whether LRP is also required for the neurite-promoting effects of nascent astrocyte-secreted apoE3 lipoproteins, we performed neurite outgrowth experiments in the presence and absence of the RAP. RAP is a competitive antagonist of all known LRP ligands (Herz et al., 1991; Strickland et al., 1991; Krieger and Herz, 1994). In the presence of RAP $(0.5 \mu \mathrm{M})$, the neuritepromoting effect of apoE3 was blocked (mean neurite length on coverslips: GFAP-apoE3, $67.4 \pm 2.2$ vs GFAP-apoE3 and RAP, $48.0 \pm 1.7 ; p<0.001$ ), whereas there was no effect of RAP on neurite outgrowth in the presence of apoE4 or the absence of apoE (data not shown). Because RAP can also interact with other members of the LDL receptor family (Battey et al., 1994), we also assessed the effects of anti-LRP and nonimmune $\mathrm{IgG}$ on neurite outgrowth. Anti-LRP IgG, at concentrations previously shown to block effects of apoE3-enriched $\beta$-very low-density lipoprotein (VLDL) on neurite outgrowth $(2 \mu \mathrm{M})$ (Holtzman et al., 1995b; Fagan et al., 1996a), also blocked the neurite-promoting effects of apoE3 secreted by GFAP-apoE3 astrocytes (Figs. 6-8). AntiLRP IgG had no effect on neurite outgrowth in the presence of GFAP-apoE4 or apoE-/- astrocytes. These findings suggest that under conditions that attempt to model those that occur physiologically in brain parenchyma, astrocyte-secreted HDL-like particles containing apoE3 but not apoE4 can mediate biological effects on neurons through interactions with LRP, an apoE receptor expressed at high levels in neurons. 


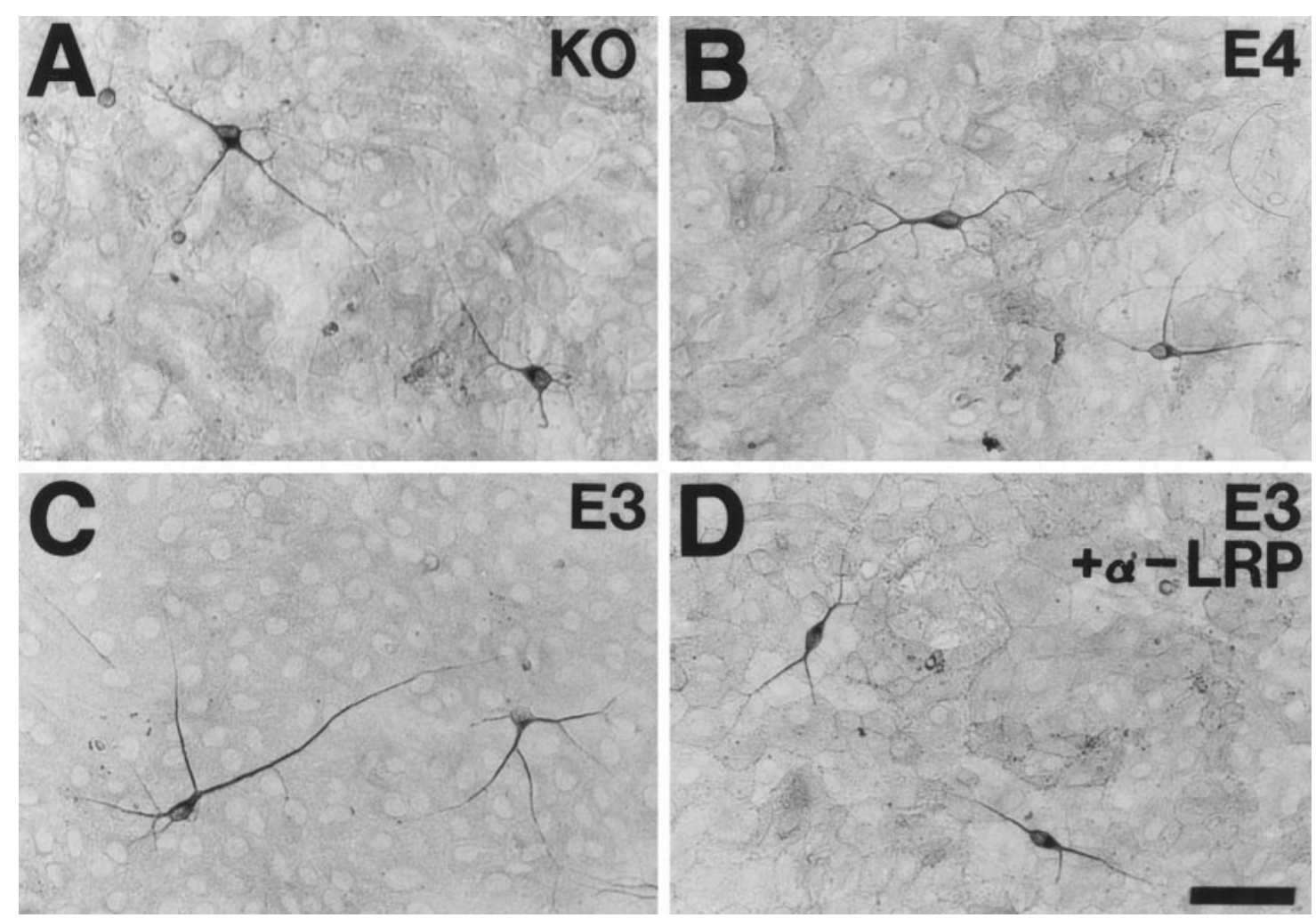

Figure 6. Neurite outgrowth from E19 primary hippocampal neurons is increased when neurons are cultured on the surface of GFAP-apoE3-secreting astrocytes. E19 primary hippocampal neurons (C57B16) were plated onto confluent astrocyte monolayers derived from the forebrain of P1 GFAP-apoE3 line $2(C, D)$, GFAP-apoE4 line $22(B)$, or apoE-/- $(A)$ littermate pups. After $44 \mathrm{hr}$ in culture, MAP-2-IR neurites were on average longer in the presence of the apoE3-secreting astrocytes than in the presence of the apoE4 or apoE-/- astrocytes. The increase in neurite outgrowth seen in the presence of apoE3 was blocked by anti-LRP IgG $(D)$. Scale bar, $26 \mu \mathrm{m}$.

\section{DISCUSSION}

Because the discovery that the $\epsilon 4$ allele of apoE is a risk factor for $\mathrm{AD}$ as well as for poor outcome after various brain insults, investigators have been studying a variety of potential avenues through which the apoE protein could account for these effects. Most of these studies have used delipidated apoE, delipidated apoE used to enrich artificial or plasma lipoproteins, or non-CNS cell line-derived apoE. Although these studies have provided useful information, the apoE produced in brain is expressed predominantly by glia (Boyles et al., 1985; Pitas et al., 1987a; Poirier et al., 1991; Nakai et al., 1996; Stone et al., 1997). Because (1) apoE in the extracellular space is found in vivo as a component of lipoproteins (including in the CNS), (2) different cell types secrete cell- and context-specific lipoproteins, and (3) the size and composition of lipoproteins affects their function, we produced a model in which human apoE isoforms are expressed by astrocytes in vivo and are regulated in a manner similar to that seen for endogenous apoE in the brain. Interestingly, cultured astrocytes from these animals secrete apoE in particles that are the size of plasma HDL and appear to influence neurite outgrowth in primary hippocampal neurons in an isoform-specific manner through the apoE receptor LRP. Further studies with this model should be useful to better understand the cellular and molecular interactions of astrocyte-produced human apoE isoforms with specific cell types and proteins in vitro and their effects in models of $\mathrm{AD}$ and other CNS disorders in vivo.

The GFAP-apoE transgenic animals expressed human apoE in astrocytes throughout postnatal brain development and into the adult period. This expression pattern is similar to what is ob- served for endogenous GFAP and apoE (Mouchel et al., 1995). The fact that apoE-IR is increased after brain injury is also similar to what is observed for the regulation of endogenous apoE (Poirier et al., 1991). The level of human apoE protein in forebrain samples from hemizygous animals was dependent on the transgenic line and in general correlated with copy number. We also found that apoE levels in adult GFAP-apoE hemizygous animals were comparable with those found in samples from adult human cortex. Although we are in the process of determining the exact amount of cross-reactivity between human and mouse apoE identified by the goat anti-apoE antibody we used to quantify human apoE in these studies, our preliminary experiments suggest that levels of mouse apoE in normal mouse brain are very similar to levels of human apoE detected in the GFAP-apoE transgenic brains (Y. Sun and D. Holtzman, unpublished observations). Thus, the level of human apoE expression in this model appears to closely mimic normal physiological levels.

Studies of CSF constituents first suggested that lipoprotein metabolism within the brain is distinct from that in the periphery (Roheim et al., 1979; Pitas et al., 1987b). The apoE in the CSF is derived from within the CNS (Linton et al., 1991). Thus, whereas apoE in plasma and other organs could influence cells within the brain through indirect mechanisms (e.g., through effects on blood vessels), effects of apoE in the brain are likely to be mediated by apoE produced within the brain itself. The GFAP-apoE transgenic mice described herein may be useful to sort out effects of astrocyte-produced apoE isoforms from effects of apoE derived from outside the brain (e.g., plasma) as well as within the brain (by astrocytes and other cells), as is seen in other human apoE 


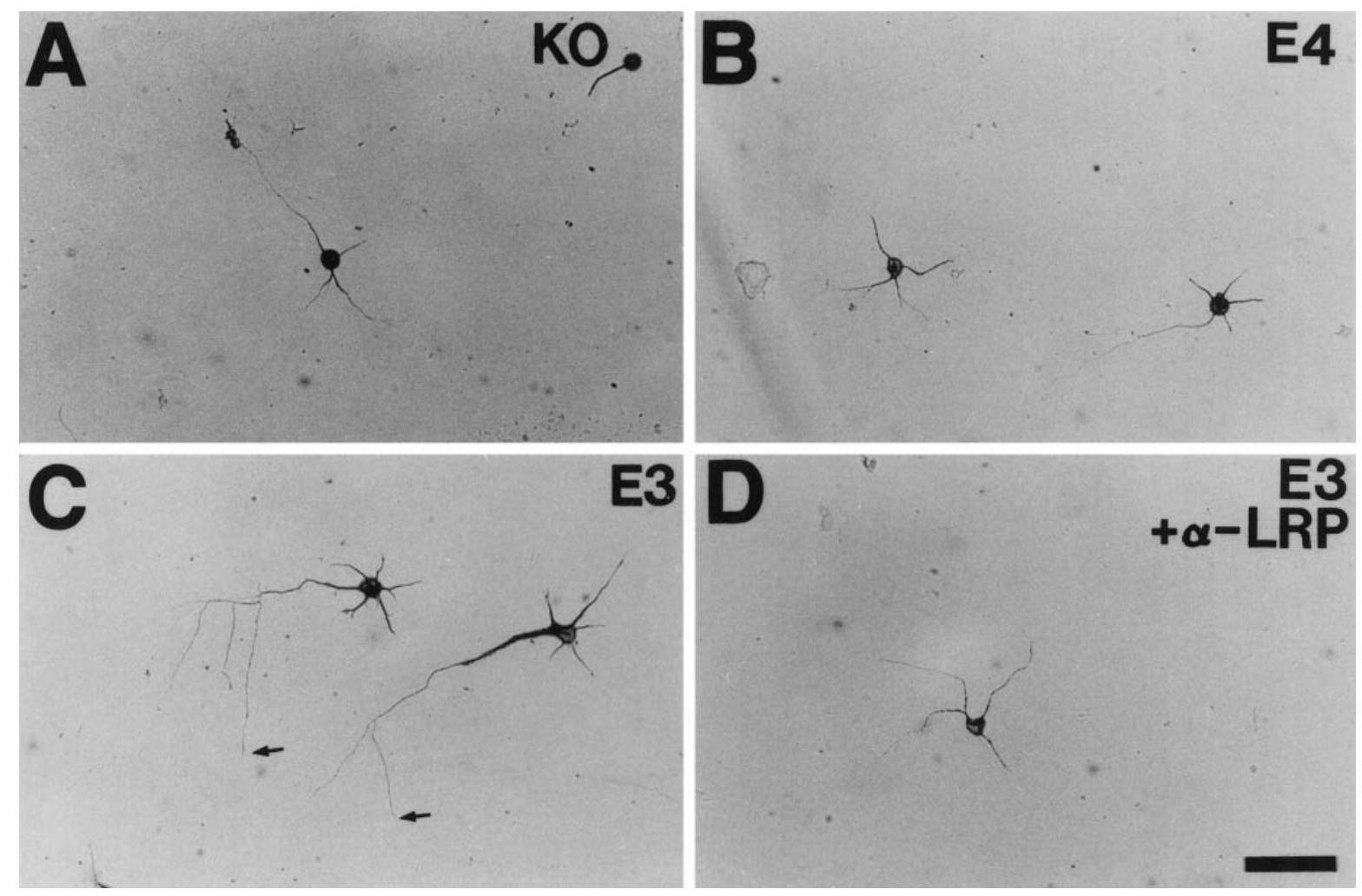

Figure 7. Neurite outgrowth from E19 primary hippocampal neurons is increased when neurons are cultured in the presence of media derived from GFAP-apoE3-secreting astrocytes. E19 primary hippocampal neurons (C57Bl6) were plated onto poly-D-lysine-coated coverslips and after attachment were incubated in the presence (but not in direct contact with) confluent astrocyte monolayers derived from the forebrain of P1 GFAP-apoE3 line 2 ( $C$, $D)$, GFAP-apoE4 line $22(B)$, or apoE-/- $(A)$ littermate pups. After $44 \mathrm{hr}$ in culture, neurites, here identified by MAP-2-IR but also identified by phase-contrast microscopy, were on average longer in the presence of the apoE3-secreting astrocytes than in the presence of the apoE4 or apoE- $/-$ astrocytes. The increase in neurite outgrowth seen in the presence of apoE3 was blocked by anti-LRP $\operatorname{IgG}(D)$. The tips of two axons are identified with arrows in $C$. Scale bar, $35 \mu \mathrm{m}$.

transgenic models. For example, human apoE transgenic mice have been produced by using different promoters driving apoE expression in brain. Mice generated with a transferrin promoter have apoE-IR in astrocytes (Bowman et al., 1995, 1996). Sullivan et al. (1997) have produced mice with a targeted replacement of human apoE3 for mouse apoE. Similar to our mice, those of Bowman et al. (1996), and wild-type mice, these mice also have apoE-IR in glia (Roses, 1997). In contrast to these three models, $\mathrm{Xu}$ et al. (1996) produced apoE transgenic animals in which large regions of human genomic DNA surrounding and including the apoE locus drive apoE expression. In these animals, apoE-IR is found in both glia and some neurons. Because apoE staining is not seen in neurons in other models, this suggests that apoE is expressed by both glia and neurons in the mice produced by $\mathrm{Xu}$ et al. (1996). Whether the structure or function of apoE and lipoproteins produced in brain by these mice (by neurons and glia) will alter the biological effects of human apoE compared with the other models in which there is only glial apoE-IR remains to be determined.

In contrast to human $\mathrm{CSF}$, which contains apoE, apoAI, apoAII, apoJ, and smaller amounts of other apolipoproteins (Roheim et al., 1979; Pitas et al., 1987b; Borghini et al., 1995), our recent studies suggest that rat astrocytes secrete lipoprotein particles that are HDL-like in size, contain only apoE and apoJ, and are composed of free cholesterol and phospholipid with little cholesteryl-ester (LaDu et al., 1998). Although we have not yet determined the composition of the lipoprotein particles secreted by the GFAP-apoE transgenic mice, the apoE that they secrete is also in particles that are HDL-like in size. In our co-culture experiments, hippocampal neurite outgrowth was augmented in the presence of apoE3-secreting astrocytes compared with that observed in the presence of apoE-/- or apoE4-secreting astrocytes. Thus, despite likely compositional and structural differences between apoE3- and apoE4-enriched plasma lipoproteins and apoE-containing, astrocyte-secreted lipoproteins, astrocytesecreted apoE isoforms appear to have similar differential effects on neurite outgrowth, as has been described in other studies with PNS neurons and on neuronal cell lines (Nathan et al., 1994; Holtzman et al., 1995b; Nathan et al., 1995). In a previous study using astrocyte-neuron co-culture techniques, we found that hippocampal neurite outgrowth is greater in the presence of astrocytes derived from wild-type mice compared with astrocytes derived from apoE-/- mice (Narita et al., 1997). Thus, with regard to neurite outgrowth, glial-derived mouse apoE particles seem to have effects similar to glial-derived human apoE3 rather than apoE4-containing particles. Although mouse apoE resembles human apoE4 at positions 112 and 158, other amino acid differences between mouse and human apoE such as at position 61 may result in mouse apoE having structural properties and lipid interactions that are more similar to human apoE3 (Weisgraber and Mahley, 1996). Whether the different effects induced by apoE3 versus apoE4 are related to differential effects on intracellular lipid metabolism (Schwiegelshohn et al., 1995), differential interactions with growth factors (Gutman et al., 1997), 
A.

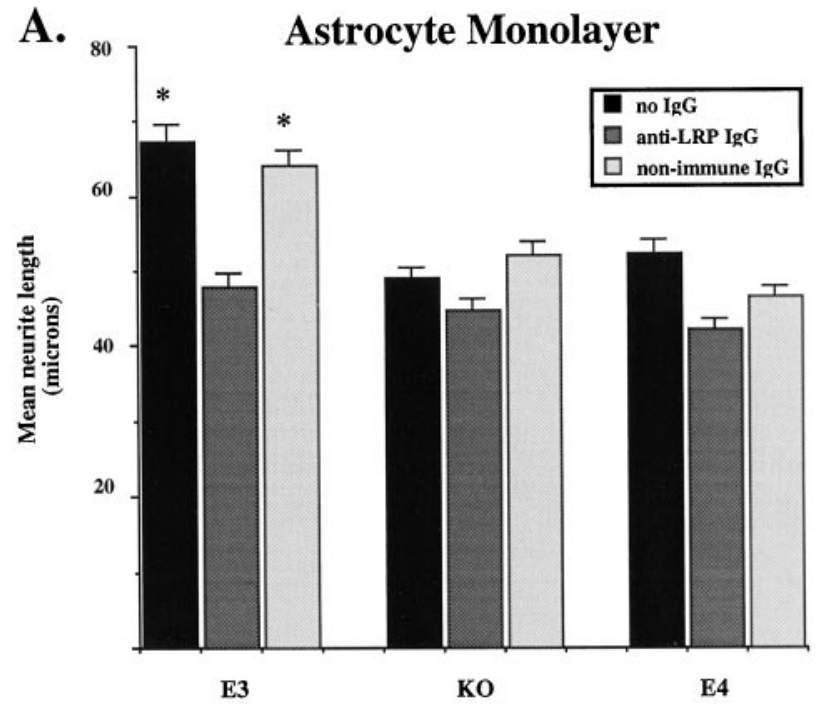

C.

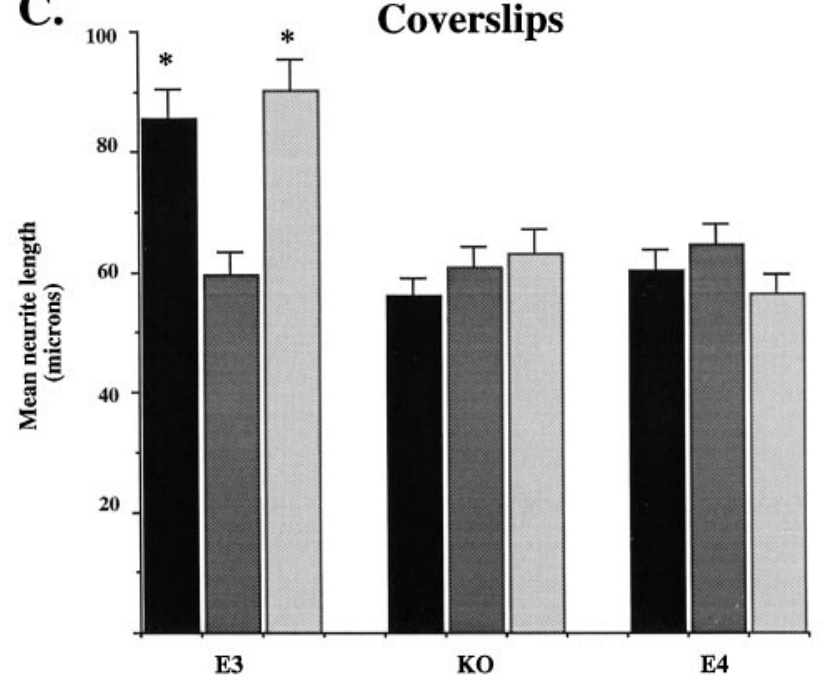

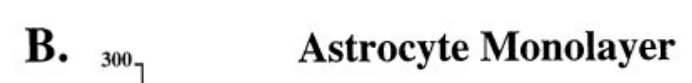

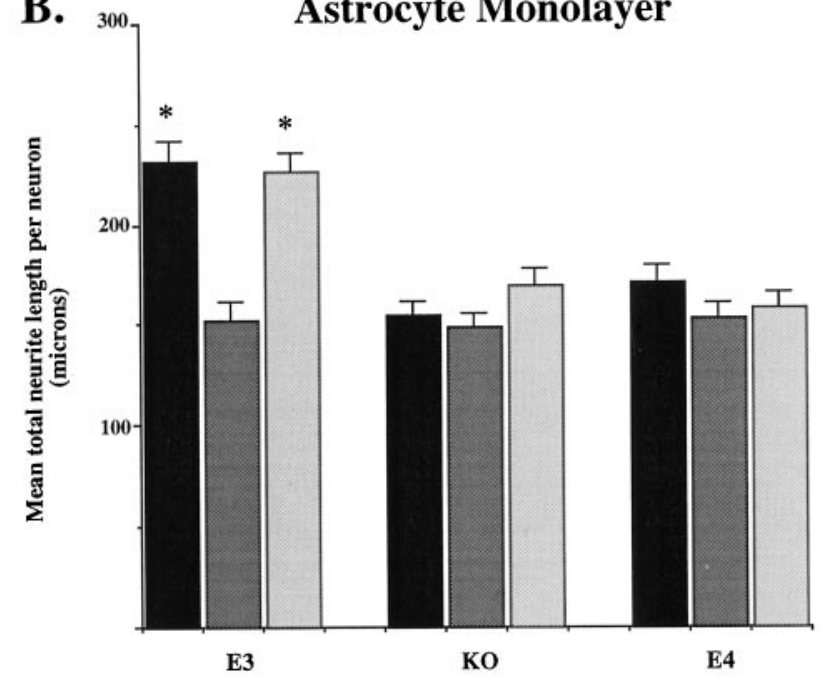

D.

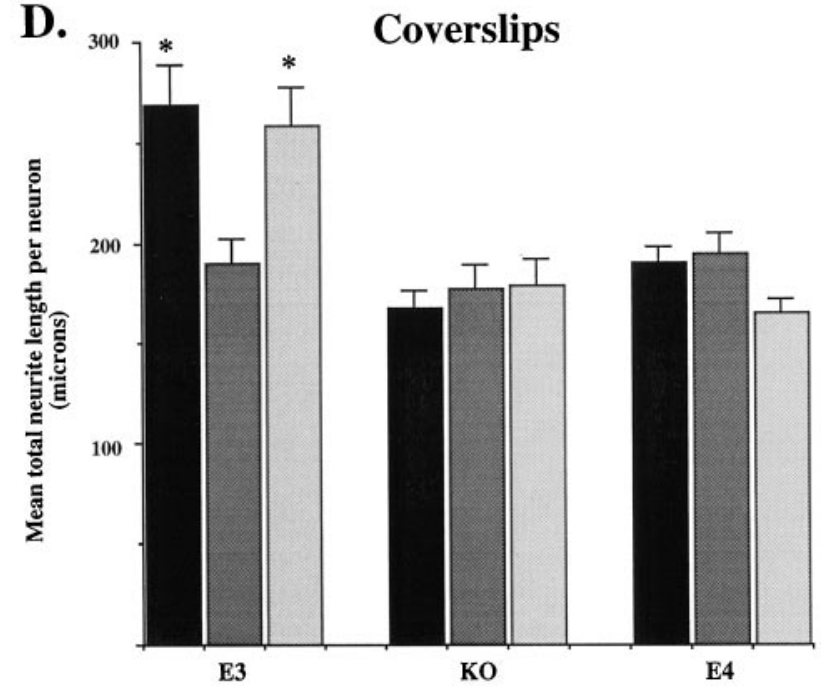

Figure 8. Quantification of neurite outgrowth in the presence of human apoE transgenic astrocytes in vitro. Primary hippocampal neurons (C57B16) were grown either directly on top of astrocyte monolayers $(A, B)$ or on poly-D-lysine-coated coverslips suspended above the astrocyte layer $(C, D)$. Mean values in a representative experiment were obtained from $n=4$ wells per condition for each transgenic line (GFAP-E3, line 2; GFAP-apoE4, line 22). In both conditions, mean neurite length and mean neurite length per neuron were significantly greater in the presence of apoE3-expressing astrocytes (E3) compared with apoE4-expressing astrocytes $(E 4)$ or those expressing no apoE $(K O)$. In addition, anti-LRP IgG significantly attenuated neurite outgrowth in the presence of apoE3-expressing astrocytes, whereas nonimmune $\operatorname{IgG}$ had no effect. Data are presented as mean $\pm \mathrm{SEM}$. ${ }^{*} p<0.05$ compared with apoE3-secreting astrocytes in the presence of anti-LRP IgG as well as apoE4 and apoE KO astrocytes under all conditions (ANOVA followed by Bonferroni $t$ test).

effects on antioxidant activity (Miyata and Smith, 1996), or effects on the cytoskeleton (Strittmatter et al., 1994; Nathan et al., 1995) remains unclear. Another possibility is that apoE isoforms differentially potentiate effects of neurite outgrowth of a protein directly linked to AD pathology. In fact, recent in vitro data suggest that apoE can directly interact with the secreted form of the amyloid precursor protein (sAPP) and can potentiate its calciumlowering effects with apoE3 having greater effects than apoE4 (Barger and Mattson, 1997). This may be important, because sAPP can itself influence neurite outgrowth (Mattson, 1994). It will be interesting to determine whether these effects require LRP. Because LRP is required for the stimulatory effects of apoE3 on neurite outgrowth in our experiments, this suggests that receptor-mediated endocytosis is in some way involved.
Previous studies with apoE3- and apoE4-enriched $\beta$-VLDL have shown no clear differences in binding to LRP (Kowal et al., 1990). Unless differences in LRP binding or uptake are found using astrocyte-derived lipoproteins, it seems likely that differential effects of apoE isoforms on neurite outgrowth will be attributed to effects of apoE on lipid and cholesterol utilization or other process subsequent to LRP-mediated endocytosis. At the developmental period during which our experiments were performed, LRP was expressed on all neuritic processes (Y. Sun and D. Holtzman, unpublished observations). However, with maturation in vitro, LRP becomes restricted to the somatodendritic domain of cultured hippocampal neurons (Brown et al., 1997). Whether this compartmentalization influences potential effects of apoE on neurons is not known. It is conceivable that differential effects of 
human apoE isoforms on neurons play a role in structural plasticity and response to brain injury that occurs in aging, in $\mathrm{AD}$ (Flood and Coleman, 1986), and after CNS insults.

Although the neurite-promoting effects of astrocytesecreted apoE3 and apoE4 suggest that these particles have similar biological activities to apoE3 and apoE4-enriched plasma $\beta$-VLDL and HDL, this does not mean that astrocytesecreted, apoE-containing particles have similar activities with regard to other potentially important interactions related to injury and disease. In addition to differential effects of apoE on structural plasticity or neuronal injury, another mechanism by which apoE4 could influence AD risk is through interactions with the $\beta$-amyloid $(\mathrm{A} \beta)$ protein, the deposition of which is thought to contribute to AD pathogenesis (Selkoe, 1994). Differential interactions between apoE isoforms and $\mathrm{A} \beta$ in brain parenchyma (Wisniewski and Frangione, 1992; Schmechel et al., 1993) may result in altered deposition or clearance of $\mathrm{A} \beta$ from the brain. Studies suggest that apoE (Strittmatter et al., 1993) and apoE-containing lipoproteins (LaDu et al., 1994, 1995) can interact with $\mathrm{A} \beta$ both in vivo (Naslund et al., 1995) and in vitro, and that apoE can also influence A $\beta$ fibril formation in vitro (Evans et al., 1994; Ma et al., 1994). Soluble A $\beta$ has been shown to interact with lipoproteins in both plasma (Biere et al., 1996) and CSF (Koudinov et al., 1996). A recent study using transgenic mice that overexpress a mutant APP transgene demonstrated than when these mice were bred onto a mouse apoE-/- background, there was a marked decrease in $\mathrm{A} \beta$ deposition and thioflavin S-positive deposits compared with animals expressing endogenous mouse apoE (Bayles et al., 1997). It will be important to determine the effects that different human apoE isoforms have on similar parameters. ApoE isoform-specific differences in astrocytesecreted particle structure may lead to differential interactions with $\mathrm{A} \beta$. Studying such interactions may give novel insights into whether apoE-containing particles secreted by astrocytes may affect $A \beta$ deposition through enhancing $A \beta$ fibrillogenesis or inhibiting $\mathrm{A} \beta$ clearance in vivo.

\section{REFERENCES}

Alberts MJ, Graffagnino C, McClenny C, DeLong D, Strittmatter W, Saunders AM, Roses AD (1995) ApoE genotype and survival from intracerebral hemorrhage. Lancet 346:575.

Barger SW, Mattson MP (1997) Isoform-specific modulation by apolipoprotein $\mathrm{E}$ of the activities of secreted $\beta$-amyloid precursor protein. J Neurochem 69:60-67.

Battey F, Gafvels ME, Fitzgerald DJ, Argraves WS, Chappell DA, Strauss JF, Strickland DK (1994) The $39 \mathrm{kDa}$ receptor associated protein regulates ligand binding by the very low density lipoprotein receptor. J Biol Chem 269:23268-23273.

Bayles KR, Verina T, Dodel RC, Du Y, Altstiel L, Bender M, Hyslop P, Johnstone EM, Little SP, Cummins DJ, Piccardo P, Ghetti B, Paul SM (1997) Lack of apolipoprotein E dramatically reduces amyloid $\beta$-peptide deposition. Nat Genet 17:263-264.

Bellosta S, Nathan BP, Orth M, Dong LM, Mahley RW, Pitas RE (1995) Stable expression and secretion of aplipoproteins E3 and E4 in mouse neuroblastoma cells produces differential effects on neurite outgrowth. J Biol Chem 270:27063-27071.

Biere AL, Ostaszewski B, Stimson ER, Hyman BT, Maggio JE, Selkoe DJ (1996) Amyloid beta-peptide is transported on lipoproteins and albumin in human plasma. J Biol Chem 271:32916-32922.

Borghini I, Barja F, Pometta D, James RW (1995) Characterization of subpopulations of lipoprotein particles isolated from human cerebrospinal fluid. Biochim Biophys Acta 1255:192-200.

Bowman BH, Jansen L, Yang F, Adrian GS, Zhao M, Atherton SS, Buchanan JM, Greene R, Walter C, Herbert DC, Weaker FJ, Chiodo LK, Kagan-Hallet K, Hixson JE (1995) Discovery of a brain promoter from the human transferrin gene and its utilization for develop- ment of transgenic mice that express human apolipoprotein E alleles. Proc Natl Acad Sci USA 92:12115-12119.

Bowman BH, Yang F, Buchanan JM, Adrian GS, Martinez AO, Jansen L, Zhao M, Atherton SL, Hixson JE (1996) Human apoE protein localized in brains of transgenic mice. Neurosci Lett 219:57-59.

Boyles JK, Pitas RE, Wilson E, Mahley RW, Taylor JM (1985) Apolipoprotein $\mathrm{E}$ associated with astrocytic glia of the CNS and with nonmyelinating glia of the peripheral nervous system. J Clin Invest 76:1501-1513.

Brenner M, Kisseberth WC, Su Y, Besnard F, Messing A (1994) GFAP promoter directs astrocyte-specific expression in transgenic mice. J Neurosci 14:1030-1037.

Brown MD, Banker GA, Hussaini IM, Gonias SL, VandenBerg SR (1997) Low density lipoprotein receptor-related protein is expressed early and becomes restricted to a somatodendritic domain during neuronal differentiation in culture. Brain Res 747:313-317.

Bu G, Maksymovitch EA, Schwartz AL (1993) Receptor-mediated endocytosis of tissue-type plasminogen activator by low density lipoprotein receptor-related protein on human HepG2 cells. J Biol Chem 268:13002-13009.

Bu G, Maksymovitch EA, Nerbonne JM, Schwartz AL (1994) Expression and function of the low density lipoprotein receptor-related protein (LRP) in mammalian central neurons. J Biol Chem 269:18521-18528.

Chen Y, Lomnitski L, Michaelson DM, Shohami E (1997) Motor and cognitive deficits in apolipoprotein E-deficient mice after closed head injury. Neuroscience 80:1255-1262.

Christie RH, Chung H, Rebeck GW, Strickland D, Hyman BT (1996) Expression of the very low-density lipoprotein receptor (VLDL-r), an apolipoprotein-E receptor, in the CNS and in Alzheimer's disease. J Neuropathol Exp Neurol 55:491-498.

Evans KC, Berger EP, Cho C-G, Weisgraber KH, Lansbury PT (1994) Apolipoprotein $\mathrm{E}$ is a kinetic but not a thermodynamic inhibitor of amyloid formation: implications for the pathogenesis and treatment of Alzheimer's disease. Proc Natl Acad Sci USA 92:763-767.

Fagan AM, Gage FH (1994) Mechanisms of sprouting in the adult CNS: cellular responses in areas of terminal degeneration and reinnervation in the rat hippocampus. Neuroscience 58:705-725.

Fagan AM, Bu G, Sun Y, Daugherty A, Holtzman DM (1996a) Apolipoprotein E-containing high density lipoprotein promotes neurite outgrowth and is a ligand for the low density lipoprotein receptor-related protein. J Biol Chem 271:30121-30125.

Fagan AM, Suhr ST, Lucidi-Phillips CA, Peterson DA, Holtzman DM, Gage FH (1996b) Endogenous FGF-2 is important for cholinergic sprouting in the denervated hippocampus. J Neurosci 17:2499-2511.

Flood DG, Coleman PD (1986) Failed compensatory dendritic growth as a pathophysiological process in Alzheimer's disease. Can J Neurol Sci 13:475-479.

Goslin K, Banker G (1991) Rat hippocampal neurons in low-density culture. In: Culturing nerve cells (Banker G, Goslin K, eds), pp 251281. Cambridge, MA: MIT.

Gutman CR, Strittmatter WJ, Weisgraber KH, Matthew WD (1997) Apolipoprotein $\mathrm{E}$ binds to and potentiates the biological activity of ciliary neurotrophic factor. J Neurosci 17:6114-6124.

Handelmann GE, Boyles JK, Weisgraber KH, Mahley RW, Pitas RE (1992) Effects of apolipoprotein E, $\beta$-very low density lipoproteins, and cholesterol on the extension of neurites by rabbit dorsal root ganglion neurons in vitro. J Lipid Res 33:1677-1688.

Herz J, Goldstein JL, Strickland DK, Ho YK, Brown MS (1991) 39 kDa protein modulates binding of ligands to low density lipoprotein receptor-related protein $/ \alpha 2$-macroglobulin receptor. J Biol Chem 266:21232-21238.

Hogan B, Costantini F, Lacy E (1986) Manipulation of the mouse embryo. Cold Spring Harbor, NY: Cold Spring Harbor Laboratory.

Holtzman DM, Bayney RM, Li Y, Khosrovi H, Berger CN, Epstein CJ, Mobley WC (1992) Dysregulation of gene expression in mouse trisomy 16, an animal model of Down syndrome. EMBO J 11:619-627.

Holtzman DM, Kilbridge J, Li Y, Cunningham ET, Lenn NJ, Clary DO, Reichardt LF, Mobley WC (1995a) TrkA expression in the CNS: evidence for the existence of several novel NGF-responsive CNS neurons. J Neurosci 15:1567-1576.

Holtzman DM, Pitas RE, Kilbridge J, Nathan B, Mahley RW, Bu G, Schwartz AL (1995b) LRP mediates apolipoprotein E-dependent neu- 
rite outgrowth in a CNS-derived neuronal cell line. Proc Natl Acad Sci USA 92:9480-9484.

Kim DH, Iijima H, Goto K, Sakai J, Ishii H, Kim HJ, Suzuki H, Kondo H, Saeki S, Yamamoto T (1996) Human apolipoprotein E receptor 2. A novel lipoprotein receptor of the low density lipoprotein receptor family predominantly expressed in brain. $\mathrm{J}$ Biol Chem 271:8373-8380.

Koudinov AR, Koudinova NV, Kumar A, Beavis RC, Ghiso J (1996) Biochemical characterization of Alzheimer's soluble beta protein in human cerebrospinal fluid-association with high density lipoprotein. Biochem Biophys Res Commun 223:592-597.

Kowal RC, Herz J, Weisgraber KH, Mahley RW, Brown MS, Goldstein JL (1990) Opposing effects of apolipoproteins E and C on lipoprotein binding to low density lipoprotein receptor-related protein. J Biol Chem 265:10771-10779.

Krieger M, Herz J (1994) Structures and functions of multiligand lipoprotein receptors: macrophage scavenger receptors and LDL receptor-related protein (LRP). Annu Rev Biochem 63:601-637.

LaDu MJ, Falduto MT, Manelli AM, Reardon CA, Getz GS, Frail DE (1994) Isoform-specific binding of apolipoprotein $\mathrm{E}$ to $\beta$-amyloid. J Biol Chem 269:23404-23406.

LaDu MJ, Pederson TM, Frail DE, Reardon CA, Getz GS, Falduto MT (1995) Purification of apolipoprotein $\mathrm{E}$ attenuates isoform-specific binding to $\beta$-amyloid. J Biol Chem 270:9030-9042.

LaDu MJ, Gilligan SM, Lukens SR, Cabana VG, Reardon CA, Van Eldik LJ, Holtzman DM (1998) Nascent astrocyte particles differ from lipoproteins in CSF. J Neurochem, in press.

Laskowitz DT, Sheng H, Bart RD, Joyner KA, Roses AD, Warner DS (1997) Apolipoprotein E-deficient mice have increased susceptibility to focal cerebral ischemia. J Cereb Blood Flow Metab 17:753-758.

Linton MF, Gish R, Hubl ST, Butler E, Esquivel C, Bry WI, Boyles JK, Wardell MR, Young SG (1991) Phenotypes of apolipoprotein $\mathrm{B}$ and apolipoprotein $\mathrm{E}$ after liver transplantation. J Clin Invest $88: 270-281$.

Ma J, Yee A, Brewer HB, Das S, Potter H (1994) Amyloid-associated proteins alpha-1-antichymotrypsin and apolipoprotein E promote assembly of Alzheimer beta-protein into filaments. Nature 372:92-94.

Mahley RW (1988) Apolipoprotein E: cholesterol transport protein with expanding role in cell biology. Science 240:622-630.

Masliah E, Mallory M, Ge N, Alford M, Veinbergs I, Roses AD (1995) Neurodegeneration in the CNS of apoE-deficient mice. Exp Neurol 136:107-122.

Mattson MP (1994) Secreted forms of $\beta$-amyloid precursor protein modulate dendrite outgrowth and calcium responses to glutamate in cultured embryonic hippocampal neurons. J Neurobiol 25:439-450.

Miyata M, Smith JD (1996) Apolipoprotein E allele-specific antioxidant activity and effects on cytotoxicity by oxidative insults and beta-amyloid peptides. Nat Genet 14:55-61.

Mobley WC, Neve RL, Prusiner SB, McKinley MP (1988) Nerve growth factor increases mRNA levels for the prion protein and the betaamyloid protein precursor in developing hamster brain. Proc Natl Acad Sci USA 85:9811-9815.

Moestrup SK, Gliemann J, Pallesen G (1992) Distribution of the $\alpha 2$ macroglobulin receptor/low density lipoprotein receptor-related protein in human tissues. Cell Tissue Res 269:375-382.

Mouchel Y, Lefrancois T, Fages C, Tardy M (1995) Apolipoprotein E expression in astrocytes: developmental pattern and regulation. NeuroReport 7:205-208.

Nakai M, Kawamata T, Maeda K, Tanaka C (1996) Expression of apoE mRNA in rat microglia. Neurosci Lett 211:41-44.

Narita M, Bu G, Holtzman DM, Schwartz AL (1997) The low density lipoprotein receptor-related protein (LRP), a multifunctional apoE receptor, modulates hippocampal neurite development. J Neurochem 68:587-595.

Naslund J, Thyberg J, Tjernberg LO, Wernstedt C, Karlstrom AR, Bogdanovic N, Gandy SE, Lannfelt L, Terenius L, Nordstedt C (1995) Characterization of stable complexes involving apolipoprotein $\mathrm{E}$ and the amyloid $\beta$ peptide in Alzheimer's disease brain. Neuron 15:219-228.

Nathan BP, Bellosta S, Sanan DA, Weisgraber KH, Mahley RW, Pitas RE (1994) Differential effects of apolipoproteins E3 and E4 on neuronal growth in vitro. Science 264:850-852.

Nathan BP, Chang KC, Bellosta S, Brisch E, Ge N, Mahley RW, Pitas RE
(1995) The inhibitory effect of apolipoprotein E4 on neurite outgrowth is associated with microtubule depolymerization. J Biol Chem 270:19791-19799.

Nicoll JAR, Roberts GW, Graham DI (1995) ApoE E4 allele is associated with deposition of amyloid beta-protein following head injury. Nat Med 1:135-137.

Piedrahita JA, Zhang SH, Hagaman JR, Oliver PM, Maeda N (1992) Generation of mice carrying a mutant apolipoprotein $\mathrm{E}$ gene inactivated by gene targeting in embryonic stem cells. Proc Natl Acad Sci USA 89:4471-4475.

Pitas RE, Boyles JK, Lee SH, Foss D, Mahley RW (1987a) Astrocytes synthesize apolipoprotein $\mathrm{E}$ and metabolize apolipoprotein E-containing lipoproteins. Biochim Biophys Acta 917:148-161.

Pitas RE, Boyles JK, Lee SH, Hui D, Weisgraber KH (1987b) Lipoproteins and their receptors in the central nervous system. J Biol Chem 262:14352-14360.

Poirier J, Hess M, May PC, Finch CE (1991) Astrocytic apolipoprotein E mRNA and GFAP mRNA in hippocampus after entorhinal cortex lesioning. Mol Brain Res 11:97-106.

Poirier J, Baccichet A, Dea D, Gauthier S (1993) Cholesterol synthesis and lipoprotein reuptake during synaptic remodelling in hippocampus in adult rats. Neuroscience 55:81-90.

Rebeck GW, Reiter JS, Strickland DK, Hyman BT (1993) Apolipoprotein $\mathrm{E}$ in sporadic Alzheimer's disease: allelic variation and receptor interactions. Neuron 11:575-580.

Roheim PS, Carey M, Forte T, Vega GL (1979) Apolipoproteins in human cerebrospinal fluid. Proc Natl Acad Sci USA 76:4646-4649.

Rose K, Goldberg MP, Choi DW (1993) Cytotoxicity in murine neocortical cell culture. In vitro biological methods. In: Methods in toxicology (Tyson CA, Frazier JM, eds), pp 46-60. San Diego: Academic.

Roses AD (1997) Apolipoprotein E, a gene with complex biological interactions in the aging brain. Neurobiol Dis 4:170-186.

Sambrook J, Fritsch EF, Maniatis T (1989) Molecular cloning: a laboratory manual. Cold Spring Harbor, NY: Cold Spring Harbor Laboratory.

Schmechel DE, Saunders AM, Strittmatter WJ, Crain BJ, Hulette CM, Joo SH, Pericak-Vance MA, Goldgaber D, Roses AD (1993) Increased amyloid $\beta$-peptide deposition in cerebral cortex as a consequence of apolipoprotein genotype in late-onset Alzheimer disease. Proc Natl Acad Sci USA 90:9649-9653.

Schwiegelshohn B, Presley JF, Gorecki M, Vogel T, Carpentier YA, Maxfield FR, Deckelbaum RJ (1995) Effects of apoprotein E on intracellular metabolism of model triglyceride-rich particles are distinct from effects on cell particle uptake. J Biol Chem 270:1761-1769.

Selkoe DJ (1994) Alzheimer's disease: a central role for amyloid. J Neuropathol Exp Neurol 53:438-447.

Slooter AJC, Tang MX, Vanduijn CM (1997) Apolipoprotein E epsilon-4 and the risk of dementia with stroke-a population based investigation. JAMA 277:818-821.

Stone DJ, Rozovsky I, Morgan TE, Anderson CP, Hajian H, Finch CE (1997) Astrocytes and microglia respond to estrogen with increased apoE mRNA in vivo and in vitro. Exp Neurol 143:313-318.

Strickland DK, Ashcom JD, Williams S, Battey F, Behre E, McTigue K, Battey JF, Argraves WS (1991) Primary structure of the $\alpha 2$ macroglobulin receptor-associated protein. $J$ Biol Chem 266: 13364-13369.

Strittmatter WJ, Roses AD (1996) Apolipoprotein E and Alzheimer's disease. Annu Rev Neurosci 19:53-77.

Strittmatter WJ, Saunders AM, Schmechel D, Pericak-Vance M, Enghild J, Salvesen GS, Roses AD (1993) Apolipoprotein E: high avidity binding to $\beta$-amyloid and increased frequency of type 4 allele in late-onset familial Alzheimer disease. Proc Natl Acad Sci USA 90:1977-1981.

Strittmatter WJ, Saunders AM, Goedert M, Weisgraber KH, Dong L-M, Jakes R, Huang DY, Pericak-Vance M, Schmechel D, Roses AD (1994) Isoform-specific interactions of apolipoprotein $\mathrm{E}$ with microtubule-associated tau: implications for Alzheimer disease. Proc Natl Acad Sci USA 91:11183-11186.

Sullivan PM, Mezdour H, Aratani Y, Knouff C, Najib J, Reddick RL, Quarfordt SH, Maeda N (1997) Targeted replacement of the mouse apolipoprotein $\mathrm{E}$ gene with the common human apoE3 allele enhances diet-induced hypercholesterolemia and atherosclerosis. J Biol Chem 272:17972-17980. 
Tardiff BE, Newman MF, Saunders AM, Strittmatter WJ, Blumenthal JA, White MD, Croughwell ND, Davis Jr RD, Roses AD, Reves JG (1997) Preliminary report of a genetic basis for cognitive decline after cardiac operations. The neurologic outcome research group of the Duke Heart Center. Ann Thorac Surg 64:715-720.

Teasdale GM, Nicoll JAR, Murray G, Fiddes M (1997) Association of apolipoprotein E polymorphism with outcome after head injury. Lancet 350:1069-1071.

Weisgraber KH, Mahley RW (1996) Human apolipoprotein E: the Alzheimer's disease connection. FASEB J 10:1485-1494.

Wisniewski T, Frangione B (1992) Apolipoprotein E: a pathological chaperone protein in patients with cerebral and systemic amyloid. Neurosci Lett 135:235-238.
Wolf BB, Loppes MBS, VandenBerg SR, Gonias S (1992) Characterization and immunohistochemical localization of alpha 2-macroglobulin receptor (low density lipoprotein receptor-related protein) in human brain. Am J Pathol 141:37-42.

Xu P-T, Schmechel D, Rothrock-Christian T, Burkhart DS, Qiu H-L, Popko B, Sullivan P, Maeda N, Saunders AM, Roses AD, Gilbert JR (1996) Human apolipoprotein E2, E3, and E4 isoform-specific transgenic mice: human-like pattern of glial and neuronal immunoreactivity in CNS not observed in wild-type mice. Neurobiol Dis 3:229-245.

Zarepesi S, Kaye J, Camicioli R, Grimslid H, Oken B, Litt M, Nutt J, Bird T, Schellenberg G, Payami H (1997) Modulation of the age at onset of Parkinson's disease by apolipoprotein E genotype. Ann Neurol 42: 655-658. 